Research Paper

\title{
Legal Problems in the Use of Banking Credit Cards in Indonesia
}

\section{Ade Pratiwi Susanty ${ }^{1}$}

${ }^{1}$ Faculty of Law, Universitas Lancang Kuning, Indonesia.

Article History

Received:

21.08 .2020

Revised:

19.09.2020

Accepted:

28.09.2020

*Corresponding Author:

Ade Pratiwi Susanty

Email:

ade_pratiwi.susanty@yahoo.co.id

This is an open access article, licensed under: $C C-B Y-S A$

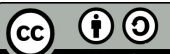

Abstract: One of the banking products in the credit sector that is becoming a trend in Indonesia is a credit card. Almost everyone who has worked has a credit card. Credit cards are usually used to facilitate payment transactions when shopping. This research aims to explain about credit cards, credit card regulations in Indonesian laws and regulations, and legal problems in the use of banking credit cards. The method used in this research is normative legal research, using a statutory approach. The research results explain that a credit card is a card-based payment instrument that can be used to make payments for obligations arising from an economic activity, including spending transactions and / or to make cash withdrawals, where the cardholder's payment obligations are first fulfilled by the acquirer or issuer, and the cardholder is obliged to make payments at the agreed time, either in lump sum (charge card) or by payment in installments. Legal problems that often occur between banks and customers using Credit Cards are defaults committed by customers because they don't pay Credit Card bills or fines billed to them and the use of debt collector services by the bank in invoicing credit card users.

Keyword: Bank, Credit Card, Legal Problems. 


\section{Introduction}

Banking is everything related to a bank, including institutions, business activities, methods and processes in carrying out its business activities. In simple terms, a bank is defined as a financial institution whose business activities are collecting funds from the public and channeling these funds back to the public, as well as providing other bank services [1]. In Law Number 10 of 1998 concerning Amendments to Law Number 7 of 1992 concerning Banking, it is explained that a bank is a business entity that collects funds from the public in the form of deposits and distributes them to the public in the form of credit and / or other forms in order to improve the standard of living of the people at large.

From some of the above definitions, we can underline that the function of a bank is as an institution for collecting and distributing funds and services. According to Law Number 7 of 1992 concerning Banking, the main function of Indonesian banking is to collect and channel public funds. First, the bank functions to collect funds from the public. The bank collects funds from the public in the form of deposits. People trust banks as a safe place to invest and save funds (money). People with excess funds really need a bank to store their funds safely. The security of the funds (money) that is kept in the bank by the public is a very important factor for the community. Apart from feeling safe, another goal is as a place to invest. People will feel safer if their money is invested in the bank. By saving their money in the bank, customers will also get benefits in the form of returns on their deposits, the amount of which depends on the policies of each bank. Second, the bank functions to channel funds to the public. Channeling funds is a very important activity for banks because the bank will get income from the funds channeled. The income obtained from channeling funds to customers is the largest income in any bank, so that channeling funds to the public is very important for the bank. The activity of channeling funds to the public, besides being an activity that can generate profits, is also for utilizing idle funds because the bank has paid a certain amount of the funds it has collected. Thus, banks mayn't allow these public funds to settle, and must immediately channel them to people in need in order to obtain income from the funds they distribute. Loans provided to the public occupy the largest portion of assets in each bank [2].

Of the various types of banking businesses, the business of extending credit occupies the most important and decisive position, considering that the credit business will assist the implementation of economic development and provide expansion of job opportunities, which in turn is intended to improve the standard of living [3]. In addition, for the bank itself, this credit is a business that provides the largest profit and income in bank receipts [4].

One of the banking products in the credit sector that is becoming a trend in Indonesia is a credit card. Almost everyone who has worked has a credit card. Credit cards are usually used to facilitate payment transactions when shopping.

Credit card is a banking business activity regulated by law. Based on Article 6 of Law Number 7 of 1992 concerning Banking, it is stated that one of the banking businesses is doing the credit card business.

From the introduction that has been described above, the formulation of the problems discussed in this research are:

1. What is a Credit Card?

2. What are the credit card regulations in the laws and regulations in Indonesia?

3. What are the legal problems in using bank credit cards?

\section{Research Methodology}

Legal research is a scientific activity based on methods, systematics, and certain thoughts that aim to study one or more specific legal phenomena by analyzing them [5]. The method used in this research is normative legal research, using a statutory approach. Normative legal research is a process to find legal rules, legal principles, and legal doctrines in order to answer legal issues faced [6]. Sources of data used in this research are secondary data, namely data obtained from statutory regulations, scientific journals, and legal literature. The data collection technique used in this research is literature study. The data analysis technique used in this research is qualitative analysis.

\section{Discussion}

Credit card is a payment instrument using a card that can be used to make payments for obligations arising from an economic activity, including spending transactions and / or to make cash withdrawals, 
where the cardholder's payment obligations are first fulfilled by the acquirer or issuer, and the card holder is obliged to make payments at the agreed time, either by paying at once (charge card) or by paying in installments.

Credit Card as defined in the applicable regulations is a business in financing activities for the purchase of goods or services using the card, which will be billed later to the User by the Credit Card Issuer.

The types of Credit Cards are as follows:

1. Bank Credit Card, is a credit card issued by a bank holding a franchise Card Company for its own customers.

2. Co-Branded Card, is a credit card issued for the benefit of certain business entities.

3. Affinity Card, is a credit card issued for the benefit of non-profit organizations.

Based on Bank of Indonesia's Regulation Number. 11/11/PBI/2009 concerning the Implementation of Card-Based Payment Instrument Activities, it is explained that Card-Based Payment Instruments, which are abbreviated as APMK, are payment instruments in the form of Credit Cards, Automated Teller Machine Cards, and / or Debit Cards. Credit Card is a Card-Based Payment Instrument that can be used to make payments for obligations arising from an economic activity, including spending transactions and / or to make cash withdrawals, where the cardholder's payment obligations are met first by the acquirer or issuer, and the card holder is obliged to make payments at the agreed time, either by paying at once (charge card) or by paying in installments.

The Automated Teller Machine Card is a Card-Based Payment Instrument that can be used to make cash withdrawals and / or transfers of funds where the cardholder's obligations are fulfilled immediately by directly reducing the cardholder's deposits at banks or non-bank institutions authorized to collect funds in accordance with statutory provisions valid invitation.

Debit Card is a Card-Based Payment Instrument that can be used to make payments for obligations arising from an economic activity, including spending transactions, where the cardholder's obligations are fulfilled immediately by directly reducing the cardholder's deposits at a bank or non-bank institution authorized to collect funds in accordance with the provisions of the applicable laws.

Credit Card Issuer is a bank or non-bank institution that issues Credit Cards. Provision of a Credit Card by a Credit Card Issuer must be based on an application signed by the prospective Credit Card holder.

Credit Card Issuers are required to provide written information to Credit Cardholders, which at least includes:

1. Procedures for using Credit Cards.

2. Important things that must be considered by Credit Card holders in using the card and the consequences or risks that may arise from the use of Credit Cards.

3. Rights and obligations of Credit Card holders.

4. Procedures for filing complaints regarding the Credit Card provided and the estimated length of time for handling such complaints.

5. Components in calculating interest.

6. Components in calculating fines.

7. Types and amounts of administrative fees charged.

As time has passed since the Bank of Indonesia's regulation regarding the implementation of CardBased Payment Instrument activities was first issued in 2004, there have been many advances in technology that have had an impact on Credit Cards. Therefore and it is also in line with input from industry, it is deemed necessary to carry out some alignment of provisions. Some of the aspects required in this adjustment include fulfilling aspects of reliability, security aspects, and system efficiency used by Credit Card operators as well as more effective supervision aspects, both through submitting reports, implementing supervision, and implementing pre-supervision through the licensing process.

Efforts to improve the creation of a national efficiency of payment systems through Credit Cards can be pursued by requiring Credit Card principals, issuers and / or acquirers to meet certain requirements such as using a reliable and mutually readable system with systems from other 
principals, issuers, and / or acquirers. By fulfilling these requirements, it can be avoided that many systems aren't connected to each other so that investment in technology equipment can be saved, which in the end will be cheaper and more efficient in the transaction process.

In terms of meeting requirements and facilitating supervision, principals, issuers and acquirers are required to obtain prior licenses from Bank of Indonesia prior to undertaking their activities. Meanwhile, in order to streamline supervision of other Credit Card providers, such as clearing operators and providers of final settlement in Credit Card transactions, the two operators have detailed the requirements for obtaining licenses and various reports that must be submitted to Bank of Indonesia.

For Credit Card personalization activity organizers which in the previous regulation required a license, Bank of Indonesia's Regulation Number 11/11/PBI/2009 concerning the Implementation of Card-Based Payment Instrument Activities no longer required a license, because it was more related to supporting activities in Credit Card administration. To fulfill the system reliability aspects and the ability to keep cardholder data confidential which must be fulfilled by the personalization company, this becomes the duty and responsibility of the Credit Card issuer when the Credit Card issuer in question cooperates with the personalization company.

In terms of the aspect of protection for Credit Card holders, several requirements that must be met by issuers haven't changed from the old Credit Card regulations, however there are several additional explanations and adjustment of formulas in accordance with the development of new laws and regulations in the field of information and electronic transactions, such as the Law on Electronic Information and Transactions. In some cases, it may be possible for the technical and micro regulations to be regulated and agreed upon by the industry itself to complement the regulations stipulated by Bank of Indonesia. However, the regulations issued mayn't conflict with policy and macro regulations stipulated by Bank of Indonesia.

Since January 1, 2014, the task of supervision of banks conducted by Bank of Indonesia was taken over by the Financial Services Authority after the enactment of Law Number 21 of 2011. The birth of the Financial Services Authority was motivated by the many cross-sectoral problems in the financial services sector between banks, capital markets, insurance, pension funds, financial institutions, and other financial service institutions so that the establishment of supervisory institutions in the integrated financial services sector was needed. Therefore, on November 22, 2011 Law Number 21 of 2011 was ratified. The Financial Services Authority was formed with the aim that all activities in the financial services sector be organized regularly, fairly, transparently and accountably; able to realize a financial system that grows sustainably and stably; and able to protect the interests of consumers and society [7].

Furthermore, considering that the payment instrument using prepaid products has developed rapidly and it is estimated that in the future the development and utilization of it will continue to vary by industry and society, of course it requires special attention, especially in terms of supervision and availability of regulations. In this regard, the regulation regarding prepaid products needs to be regulated in a more complete manner in a separate Bank of Indonesia's regulation that is separate from the Credit Card regulation.

Crimes against card-based payment instruments have been increasing and varying so that a more detailed regulation is needed regarding compliance with aspects of security and system reliability. In order to provide better service to cardholders, a more active role is needed from the principal, issuer, acquirer, clearing operator, and organizer of the final settlement.

With the service in the form of a Credit Card provided by the bank, it has made it easier for people who don't have enough money to be able to buy the goods or services they want, then pay them gradually to the bank.

Legal problems that often occur between banks and customers using Credit Cards are defaults committed by customers because they don't pay Credit Card bills that are billed to them.

Based on Bank Indonesia's Regulation Number 11/11/PBI/2009 concerning the Implementation of Card-Based Payment Instrument Activities, it is stated that Credit Card Issuers are required to include information in the billing sheet submitted to Credit Cardholders, which at least includes:

1. The minimum amount of payment by Credit Card holders.

2. Payment due date. 
3. The amount of the percentage of interest per month and the effective percentage of interest per year (annualized percentage rate) of transactions made, including interest on transactions for purchases of goods or services, cash withdrawals, and other benefits from Credit Cards if the interest on each transaction is different.

4. The amount of fines for late payments by Credit Card holders.

5. The nominal interest charged.

The provision of Credit Card facilities as stated in a credit agreement by the bank to customers isn't without risk. This risk may occur especially because the debtor isn't obliged to pay his debt in full or in cash, but rather the debtor is entrusted by law through a credit agreement to pay his debt in stages.

Risks that generally occur are failure or congestion in credit repayment which is called credit risk, risks that arise due to market movements which are called market risks, risks due to banks being unable to fulfill their matured obligations which are called liquidity risks, and risks due to weaknesses in juridical aspects which is caused by the absence of supporting legislation which is called legal risk $[8,9]$.

Therefore, in providing Credit Card facilities to customers, each bank is required to take methods that aren't detrimental to the bank and the interests of the customer who entrusts their funds to the bank. Considering that banks mainly work with funds from the public that are deposited in banks on the basis of trust, each bank needs to continue to maintain its health and maintain public trust in it.

The application of the principles of good corporate governance is necessary to build public and international trust as an absolute prerequisite for the banking sector to develop properly. Therefore, the Bank for International Sattlement as an institution that studies the prudential principles that banks must adhere to has issued guidelines for the implementation of good corporate governance for the banking sector internationally [10].

As for some examples of legal problems regarding credit cards between customers and banks that have reached the court and have been decided by the judge, they are as follows:

1. Sutrisno vs. Mandiri Bank Case

2. Victoria vs. Standart Chartered Bank Case

3. Hagus vs. Citibank Case

\subsection{Sutrisno vs. Mandiri Bank Case}

Sutrisno (Plaintiff), a wood furniture entrepreneur from Wonogiri, sued Mandiri Bank (Defendant) because his requests for business capital loans were always rejected by the bank. This is because Mandiri Bank through the Credit Card Division has issued an invoice dated March 6, 2013 for the arrears in the use of a Credit Card amounting to IDR 8,000,000 (eight million rupiah), even though Sutrisno has never entered into an agreement to use the Defendant's Credit Card facility, let alone make purchase transactions with the Defendant's Credit Card.

In the invoice, there is a clear and real difference in the name and business address of the Plaintiff, because it is written a / n CV Mulia Jaya at Raya Pucangsawit Street Number of 205, RT 03 / RW 05, Pucangsawit Village, Jebres Sub-District, Surakarta City. Even though the plaintiff's trade name is UD Anugerah, having its address at Gondang Kulon RT 02 / RW 05, Purwosari Village, Wonogiri Sub-District, Wonogiri Regency.

Therefore, the Court then gave the consideration that the Defendant's act of not immediately issuing a letter to remove the black list status regarding the Plaintiff's trading business and this was done due to the Defendant's negligence, this was an act that violated the law or was against the Plaintiff's subjective rights, so the District Court Surakarta sentenced the Defendant to pay compensation to the Plaintiff in the amount of IDR 100,000,000 (one hundred million rupiah).

\subsection{Victoria vs. Standart Chartered Bank Case}

Victoria sued Standard Chartered Bank because she felt that she was immaturely disadvantaged by the treatment carried out by Standard Chartered Bank. This case began when Victoria had difficulty repaying credit without credit card collateral to Standard Chartered Bank, which then Standard Chartered Bank threatened and carried out terror by sending a fax to Victoria's superiors. 
Victoria sued Standard Chartered Bank by demanding compensation of 5 billion rupiah because the use of debt collectors was considered illegal. At the District Court level, Standard Chartered Bank lost and was sentenced to pay IDR 10,000,000 (ten million rupiah). At the High Court level, the sentence was increased to IDR 500,000,000 (five hundred million rupiah).

Meanwhile, at the cassation level the Standard Chartered Bank was punished to pay 1 billion rupiah. Standard Chartered Bank in conducting credit collection is an unprofessional action because it prioritizes the use of intimidation and thuggery approaches rather than other approaches that place customers as bank partners.

\subsection{Hagus vs. Citibank Case}

The South Jakarta District Court decided to sentence Citibank not to collect stamp duty on the customer's Visa and Master Credit Card bills on behalf of Hagus. This is because the judge believes that the collection of fees has no legal basis.

The application of stamp duty cann't be carried out unilaterally, but there must be an agreement from each party, so that Citibank is deemed to have committed an illegal act. The judge then ordered Citibank to return the stamp fee that had been collected to Hagus from March 2000 to September 2005 in the amount of IDR 384,000 (three hundred and eighty-four thousand rupiah).

So, the legal problems that often occur between banks and customers using Credit Cards are defaults committed by customers because they don't pay Credit Card bills or fines billed to them and the use of debt collector services by the bank in invoicing credit card users.

Regarding defaults committed by customers for not paying credit card bills or fines billed to them, the bank usually takes persuasive steps first.

After that, the bank provides options to customers as follows:

1. Rescheduling

Which is the settlement of bad credit by extending the credit period, so that customers will be given relief to pay their obligations.

2. Reconditioning

Namely the settlement of bad credit which is carried out by changing various existing requirements, such as postponing interest payments, lowering interest rates, or waiving interest on the basis that the customer is deemed unable to pay it again, then the customer is only required to pay off the principal debt only .

3. Restructuring

Namely the settlement of bad credit by increasing capital for a customer's business because the business is considered capable of getting up and developing.

\section{Conclusion}

Credit Cards are Card-Based Payment Instruments that can be used to make payments for obligations arising from an economic activity, including spending transactions and / or to make cash withdrawals, where the cardholder's payment obligations are fulfilled first by the acquirer or issuer, and the card holder is obliged to make payments at the agreed time, either by paying at once (charge card) or by paying in installments.

Legal problems that often occur between banks and customers using Credit Cards are defaults committed by customers because they don't pay Credit Card bills or fines billed to them and the use of debt collector services by the bank in invoicing credit card users.

\section{References}

[1] Kasmir, Banking Basics. Jakarta: Rajawali Pers, 2012.

[2] Ismail, Banking Management; From Theory to Application. Jakarta: Kencana, 2011.

[3] A. S. Utama, "Independency of Supervision of State-Owned Enterprises of Banks in the National Legal System in Indonesia," Soumatera Law Review Journal, vol. 1, no. 1, pp. 1-21, 2018.

[4] T. Suyatno, Banking Institutions. Jakarta: PT Gramedia Pustaka Utama, 1997.

[5] S. Seokanto, Introduction to Legal Research. Jakarta: UI Press, 2007.

[6] P. M. Marzuki, Legal Research. Jakarta: Kencana, 2011. 
Ade Pratiwi Susanty.

Legal Problems in the Use of Banking Credit Cards in Indonesia.

International Journal of Law and Public Policy, vol. 2, no. 2, pp. 72-78, September 2020. DOI: 10.36079/lamintang.ijlapp-0202.148

[7] A. S. Utama, "Supervision of Islamic Banking Based on Law Number 21 of 2011," Proceeding of International Conference on Humanity, Law, and Sharia, vol. 1, no. 1, pp. 109-112, 2018.

[8] B. Harun, Non Performing Credit Dispute Resolution. Yogyakarta: Pustaka Yustisia, 2010.

[9] I. P. Nugraha, R. Njatrijani, and Aminah, "Analisis Pelaksanaan Lelang Terhadap Benda Jaminan Hak Tanggungan Atas Pengajuan Kredit Sebagai Akibat Wanprestasi Berdasarkan Undang-Undang Nomor 4 Tahun 1996 (Studi Kasus Pada Putusan Nomor: 457/Pdt.G/2014/ Pn.Smg)," Diponegoro Law Journal, vol. 5, no. 3, 2016.

[10] A. S. Utama, "Good Corporate Governance Principles in Indonesia Syariah Banking," International Journal of Law and Public Policy, vol. 2, no. 1, pp. 11-16, 2020. 